San Jose State University

SJSU ScholarWorks

Master's Theses

Master's Theses and Graduate Research

1997

\title{
The effects of REM sleep deprivation on epileptiform activity in a rat hippocampal brain slice
}

Amite Dominick

San Jose State University

Follow this and additional works at: https://scholarworks.sjsu.edu/etd_theses

\section{Recommended Citation}

Dominick, Amite, "The effects of REM sleep deprivation on epileptiform activity in a rat hippocampal brain slice" (1997). Master's Theses. 1435.

DOI: https://doi.org/10.31979/etd.xzfx-e69u

https://scholarworks.sjsu.edu/etd_theses/1435

This Thesis is brought to you for free and open access by the Master's Theses and Graduate Research at SJSU ScholarWorks. It has been accepted for inclusion in Master's Theses by an authorized administrator of SJSU ScholarWorks. For more information, please contact scholarworks@sjsu.edu. 


\section{INFORMATION TO USERS}

This manuscript has been reproduced from the microfilm master. UMI films the text directly from the original or copy submitted. Thus, some thesis and dissertation copies are in typewriter face, while others may be from any type of computer printer.

The quality of this reproduction is dependent upon the quality of the copy submitted. Broken or indistinct print, colored or poor quality illustrations and photographs, print bleedthrough, substandard margins, and improper alignment can adversely affect reproduction.

In the unlikely event that the author did not send UMI a complete manuscript and there are missing pages, these will be noted. Also, if unauthorized copyright material had to be removed, a note will indicate the deletion.

Oversize materials (e.g., maps, drawings, charts) are reproduced by sectioning the original, beginning at the upper left-hand corner and continuing from left to right in equal sections with small overlaps. Each original is also photographed in one exposure and is included in reduced form at the back of the book.

Photographs included in the original manuscript have been reproduced xerographically in this copy. Higher quality 6" $\times 9$ " black and white photographic prints are available for any photographs or illustrations appearing in this copy for an additional charge. Contact UMI directly to order.

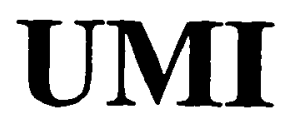

A Bell \& Howell Information Company 

THE EFFECTS OF REM SLEEP DEPRIVATION ON EPILEPTIFORM ACTIVITY IN A RAT HIPPOCAMPAL BRAIN SLICE

\author{
A Thesis \\ Presented to \\ the Faculty of the Department of Psychology \\ San Jose State University
}

In Partial Fulfillment

of the Requirements for the Degree

Master of Arts

by

Amite Dominick

May 10, 1997 
UMI Number: 1384684

UMI Microform 1384684

Copyright 1997, by UMI Company. All rights reserved.

This microform edition is protected against unauthorized copying under Title 17, United States Code.

\section{UMI \\ 300 North Zeeb Road \\ Ann Arbor, MI 48103}




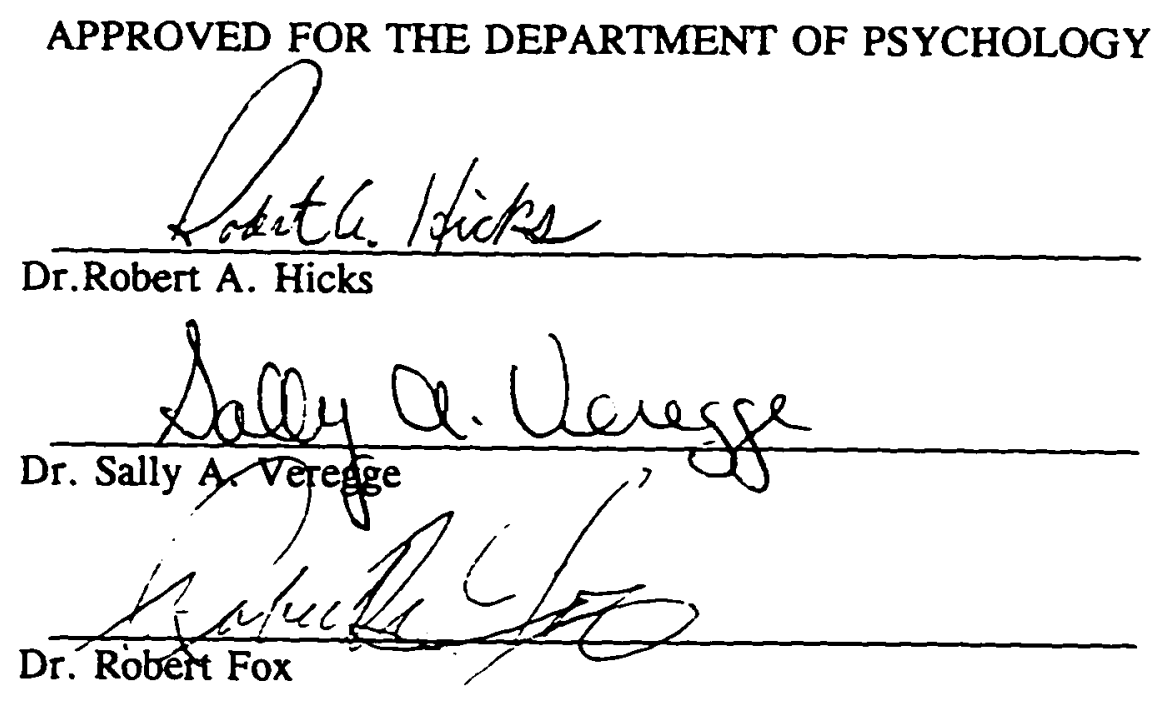

APPROVED FOR THE UNIVERSITY

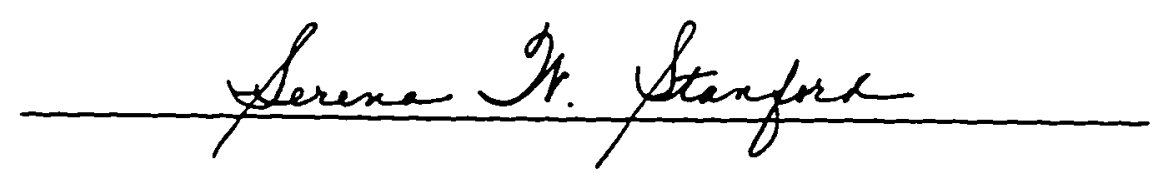


01997

Amite R. Dominick 


\section{ABSTRACT \\ SEIZURES IN A RAT HIPPOCAMPAL BRAIN SLICE \\ by Amite Dominick}

The purpose of this study was to examine the effects of REM sleep deprivation (RSD) on the susceptibility of rat hippocampal slices to epileptogenic electrical stimuli. Hippocampal slices were extracted from control and REM deprived, 31 day-old, male Sprauge Dawley rats. Slices received 10, high-intensity electrical stimulus trains, repeated at 5-minute intervals, in order to elicit epileptiform activity. Fewer stimuli were needed to evoke epileptiform activity in hippocampal slices from the RSD rats than in slices from rats who were not RSD, $\underline{t}(21)=2.17, \mathrm{p}<.05$, and more population spikes were present in the experimental groups after 10 stimulus trains than in the control group $\underline{\mathrm{t}}(21)=-2.63, \mathrm{p}<.05$. In addition, the data suggest a dose related effect of the RSD, as well as a recovery effect $t(22)=3.17, \mathrm{p}<.05$. These findings support previous studies which assert that RSD facilitates epileptiform activity. 
TABLE OF CONTENTS

Section

P a g e

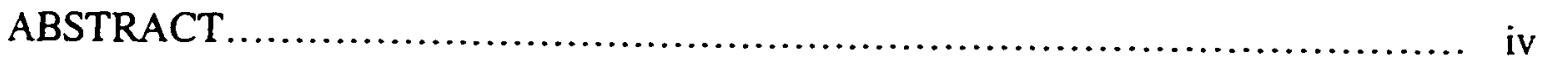

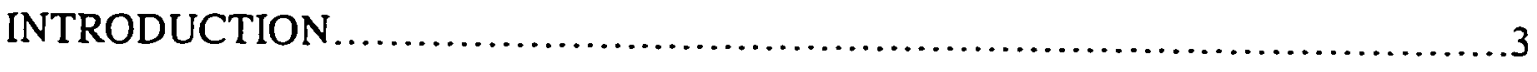

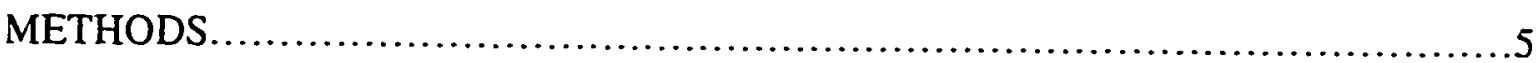

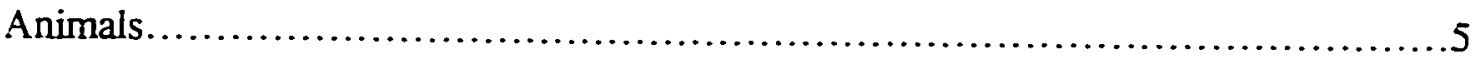

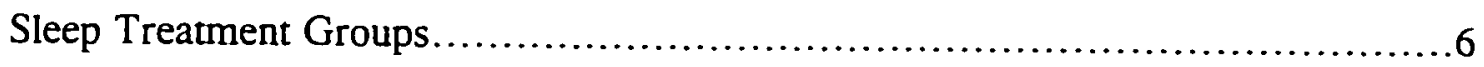

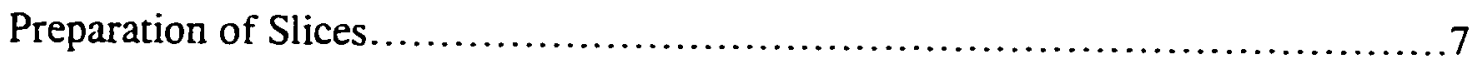

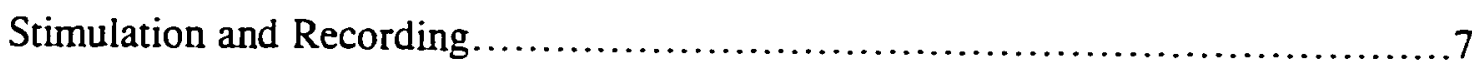

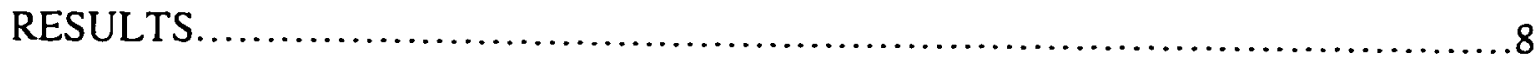

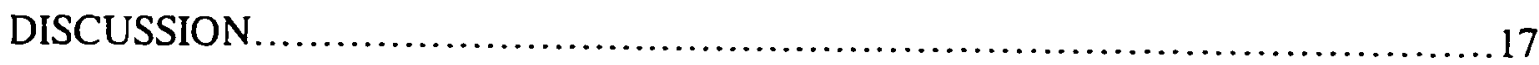

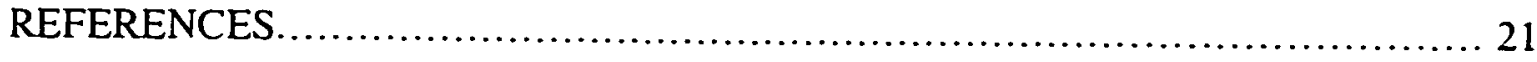




\section{LIST OF TABLES}

Table

Page

1. Means (M) and Standard Deviations (SE) for the Number of Spikes Present after 10 Stimulus Trains and the Number of Stimulus Trains Required to Produce Epileptiform Activity

2. Statistical Comparisons for Spikes Present after 10 Stimulus Trains and the Number of Stimulus Trains Required to Produce Epileptiform Activity. 


\section{LIST OF FIGURES}

Figure Page

1. Means of the Number of Stimulus Trains Required

to Produce an Epileptiform Response.

2. Means for the Number of Population Spikes

Present after 10 Stimulus Trains. 
THE EFFECTS OF REM SLEEP DEPRIVATION ON EPILEPTIFORM ACTIVITY

IN A RAT HIPPOCAMPAL BRAIN SLICE BRAIN SLICE

Amite R. Dominick

San Jose State University

Running Head: RSD EFFECTS ON EPILEPSY IN THE RAT HIPPOCAMPUS 


\section{PLEASE NOTE}

\section{Page(s) not included with original material}

and unavallable from author or university. Filmed as recoived. 


\section{Esd Effects}

3

\section{THE EFFECTS OF REM SLEEP DEPRIVATION ON EPILEPTIFORM ACTIVITY}

\section{IN A RAT HIPPOCAMPAL BRAIN SLICE}

According to Passouant (1984), "Sleep is an essential function of the Central Nervous System (CNS): epilepsy is a common anomaly of the CNS. Therefore, sleep and epilepsy are frequently reiated to each other" (p.10). Consistent with this view, clinical and experimental data have shown a relationship between seizures and Rapid Eye Movement (REM) sleep. For example, it has been observed that ictal and interictal epileptic activities are affected by wakefulness, sleep, and different phases of sleep (Hopkins \& Garman, 1987; Rossi, Colicchio, Pola \& Roselli, 1984). Further, it is well documented that sleep deprivation facilitates the appearance of seizures, and is often used as a means of activation in order to demonstrate a focus of seizures in epileptic subjects. Finally, it has been demonstrated that full deprivation of REM sleep alone, lowers the convulsive threshold for electroconvulsive shock in both rats and cats (Cohen \& Dement 1965, 1966).

Although clinical and experimental data have shown a relationship between sleep and seizures, these findings tend to be somewhat controversial. Some studies indicate that certain types of seizure activity may be present during REM sleep. There also appears to be an increase of excitability in certain areas of the cerebral cortex during REM sleep (Palestini, Pisano, Rosadini, \& Rossi, 1965; Rossi, Palestini, Pisano, \& Rosadini, 1965). Other studies have shown that REM sleep may be "the triggering 


\section{Esd Effects}

4

agent in partial seizures" (Cadihac, 1982, p.7). Absence seizures are believed to occur only during wakefulness. However, recent studies have shown that regular spike wave discharges similar to those occurring in clinical seizures were also activated during REM sleep (Horita, Uchida, \& Maekawa, 1991). In addition, absence seizures in rats can be reduced by REM deprivation (Peeters, Van Luijtelaar, \& Coenen, 1988).

In contrast to the data suggesting that REM sleep may facilitate interictal or ictal activity, the results of other studies that measured the potential influence that REM sleep has on seizures suggest that REM activity is much like that of wakefulness and may have more of a inhibitory effect on seizures (Cohen, Thomas, \& Dement, 1970). Others have reported less epileptic seizure activity during REM sleep than in other stages of sleep. Also, these investigators noted that maximal interictal spiking rates occurred in Non-REM sleep and that spiking rates decreased during REM sleep (e.g.,Billiard, Besset, Zachsriev, Touchon, Baldy, Moulinier, \& Cadihac, 1987; Montplaisir, Laverdiere, \& Saint-Hilaire, 1982, 1985; Montplaisir, Laverdiere, SaintHilaire, \& Rouleau 1987a, 1987b; Sammaritano, Gigli, \& Gotman, 1991). In addition. Shouse, Langer, and Dittes (1990) found that generalized seizure activity was suppressed during stable REM sleep in temporal lobe epilepsy. Seizure susceptibility was highest during slow wave sleep (SWS) at the REM transition and lowest during stable REM sleep. 


\section{Esd Effects}

Although the previous studies all agree that there is some relationship between REM sleep and epilepsy, the exact nature of this relationship is uncertain. There are a number of possible reasons why disagreement exists among researchers about the effects of REM sleep on epilepsy. For example, different investigators have studied different regions of the brain. In addition, investigators have used assorted models of epilepsy and several species of animals.

In a attempt to further explore the relationship between REM sleep and seizures, I have examined the effects of REM deprivation on the susceptibility of rat hippocampal slices to epileptogenic electrical stimuli. I chose the in vitro method in order to examine the direct effects of REM deprivation on epileptiform activity in the hippocampus. The hippocampus is a region of the temporal lobe that is highly susceptible to epilepsy and that is thought to be involved in many temporal lobe epileptic seizures (Schwartzkroin \& Prince, 1978; Yamamoto, 1972: Yamamoto \& Kawai, 1968). Based on evidence from the studies described above, I hypothesized that the hippocampal slices from rats that have been deprived of REM sleep would be more susceptible to epileptogenic stimulation.

Methods

\section{Animals}

I used male Sprague-Dawley rats, 22 days old at the time of delivery, for my experiments. These rats were maintained under controlled lighting ( 12 hours light/12 


\section{Esd Effects}

6

hours dark), and temperature conditions $\left(70^{\circ}-75^{\circ} \mathrm{F}\right)$. Rats were provided with food and water ad libitum. Approximately 10 rats per group were used.

\section{Sleep Treatment Groups}

Thirty-one day-old male Sprague Dawley rats were assigned to three experimental and two control groups. All groups received a 9- day adaptation period prior to any treatment. The three experimental groups consisted of a 2-day REM sleep deprived group (RSD), a 4-day RSD group, and a 4-day RSD group with a 4-day recovery period. The two control groups were similar to the 4-day RSD and the 4-day RSD groups with recovery except that no treatment was administered. Deprivation of REM sleep was accomplished by the use of the platform method (Hicks, Gomez, Gonzales, McTighe, \& Ortiz, 1988). During REM sleep deprivation, all animals were housed in 18.9-liter buckets that were modified so that food and water was available ad libitum from a feeder on the side of the cage. The top of the bucket was covered with a wire mesh, and the water bottle was positioned so that the spout was within easy reach of the animals. During the treatment time, each animal in the RSD conditions spent its time in the bucket on a $6.5-\mathrm{cm}$ platform that was surrounded by water $\left(19^{\circ} \mathrm{C}\right)$ to within $1 \mathrm{~cm}$ of the platform. The animals in the control group (group number 1 and group 5 , which recieved no REM deprivation) were treated identically, with the exception that these animals spent the entire treatment period on a larger platform $(16.5-\mathrm{cm})$ that was not surrounded by water. Tissue from only one animal was tested on a given day, and 


\section{Esd Effects}

7

all tests were done during the same time of day. A minimum of two animals were tested per week until all of the treatment conditions of the experiment were adequately evaluated.

\section{Preparation of Slices}

Each rat was anesthetized with Metofane and then decapitated. The brain was then removed and bisected. The dorsal surface of one cerebral hemisphere was removed by making a slice perpendicular to the midbrain. The brain was mounted on its dorsal surface in the holding chamber of a vibratome. Ice cold artificial cerebrospinal fluid (ACSF) was poured over the brain until it was completely submerged. Approximately $2-4,500 \mu \mathrm{m}$ thick, hippocampal slices were prepared from each rat (preferably from the right hemisphere of the brain). Hippocampal slices were then placed in an incubation chamber that contained ACSF (124 mM NaCl, $5 \mathrm{mM} \mathrm{KCl}, 1.25 \mathrm{mM}$ $\mathrm{NaH}_{2} \mathrm{PO}_{4}, 2 \mathrm{mM} \mathrm{MgSO}_{4}, 26 \mathrm{mM} \mathrm{NaHCO}_{3}, 10 \mathrm{mM}$ dextrose, $2 \mathrm{mM} \mathrm{CaCl}$ ). The incubation chamber was oxygenated with a gas mixture of $95 \%$ oxygen and $5 \%$ carbon dioxide. Slices were allowed to equilibrate for a period of approximately 1.5 hours.

\section{Stimulation and Recording}

After the slices had equilibrated, I placed one slice in an interface recording chamber (Haas, Schaerer, \& Vosmansky, 1979). This chamber was perfused with ACSF at a flow rate of 0.5 to $0.67 \mathrm{ml}$ per minute and aerated with a gas mixture of $95 \%$ oxygen and $5 \%$ carbon dioxide. The temperature was maintained at $80^{\circ}$ to $95^{\circ} \mathrm{F}$. 


\section{Esd Effects}

8

A glass recording electrode $(2-10 \mathrm{M} \Omega$, filled with $2 \mathrm{M} \mathrm{NaCl})$ was placed in the CAl pyramidal cell body layer, and a tungsten stimulating electrode was placed in the Schaffer collaterals.

I orthodromically stimulated the CAl pyramidal cells to evoke a field potential of no less than $2 \mathrm{mV},(0.1 \mathrm{~Hz}$, at a $100 \mu$ s stimulus duration). The stimulus intensity ranged from 120 to $1420 \mu \mathrm{A}$. Once I established that the slices were viable and determined the stimulus intensity that produced the maximal response, I began giving the slices a high frequency orthodromic train of stimuli $(60 \mathrm{~Hz}, 2 \mathrm{~s}$ duration, at 1.5 times the stimulus intensity required for a maximal response). This stimulus train was repeated at 5 -minute intervals for 10 consecutive trains to induce seizure-like activity.

The parameters measured were the number of population spikes present in the field potential after the last stimulus train and the number of stimuli required to induce an epileptiform field potential. A field potential was defined as epileptiform if it had two or more population spikes. The number of population spikes was counted at $1 \mathrm{~min}$ and 4 min post-stimulation over the course of the 10 stimulus trains.

\section{Results}

A series of $t$ statistics were computed to compare the number of population spikes and the number of trains needed to produce more than one population spike in the different groups. 


\section{Esd Effects}

9

Means and standard deviations for the number of population spikes present after 10 stimulus trains and the number of stimulus trains required to invoke a epileptiform response for each experimental condition are shown in Table 1. More population spikes were present in the experimental groups (2-day RSD 2.45/-1.37, 4-day RSD $3.17+/-1.12)$

after 10 stimulus trains than in the control group $(2.00+/-1.00)$. In addition, fewer stimuli were needed to evoke epileptiform activity in hippocampal slices from the RSD rats (2-day $3.18+/-2.40,4$-day $\operatorname{RSD} 2.33+/-2.57$ ) than in slices from rats who were not $\operatorname{RSD}(5.18+/-3.68)$. 
Esd Effects

10

Table I

Means and Standard Deviations for the Number of Spikes Present after 10 Stimulus

Trains and the Number of Stimulus Trains Required to Produce Epileptiform Activity.

Number of Spikes Number of Stimulus Trains

Condition

$\underline{\mathrm{X}} \quad \underline{\mathrm{S} . \mathrm{D}}$.

$\underline{X} \quad \underline{S} . \mathrm{D}$.

$\underline{\mathrm{n}}$

Control

$2.00 \quad 1.00$

$5.18 \quad 3.68$

11

2-day RSD

$2.45 \quad 1.37$

$3.18 \quad 2.40$

12

4-day RSD

$3.17 \quad 1.12$

$2.33 \quad 2.57$

12

4-day RSD with recovery

$2.42 \quad .90$

$3.25 \quad 2.96$

12

4-day Control with recovery

$1.83 \quad .94$

$5.25 \quad 3.88$

12 


\section{Esd Effects}

11

Statistical comparisons between the control and experimental groups are shown in Table II . The means for the 4-day RSD group were significantly different from the control groups for both the number of stimulus trains and the number of population spikes $(\underline{\mathrm{t}}(21)=2.17, \mathrm{p}<.05, \underline{\mathrm{t}}(21)=-2.63, \underline{\mathrm{p}}<.05)$. In addition there was a significant difference between the 4-day RSD group and the 4-day control with recovery group $(\underline{\mathrm{t}}(22)=3.17, \underline{\mathrm{p}}<.05)$.

The means for the number of stimulus trains required to produce an epileptiform response decreased with an increase in the number of days of REM deprivation and increased with the number of days of recovery (Figure 1), while the means for the numberof population spikes present after 10 stimulus trains increased as the number of days of REM deprivation increased and decreased as the number of days of recovery increased (Figure 2). Both these findings suggest that there is a dose-related effect of the RSD. 
Esd Effects

12

Table II

Statistical Comparisons for Spikes Present after 10 Stimulus Trains and the Number of

Stimulus Trains Required to Produce Epileptiform Activity

\begin{tabular}{|c|c|c|c|c|}
\hline \multirow[b]{2}{*}{ Comparisons } & \multicolumn{2}{|c|}{ Spikes } & \multicolumn{2}{|c|}{ Trains } \\
\hline & t-value & p & t-value & $\mathrm{p}$ \\
\hline Control vs. 2-day RSD & 0.89 & .192 & 1.51 & .074 \\
\hline Control vs. 4-day RSD & 2.63 & $.008 * *$ & 2.17 & $.021 *$ \\
\hline \multicolumn{5}{|l|}{ 4-day RSD with recovery vs. } \\
\hline 4-day Control with recovery & 1.55 & .067 & 1.42 & .085 \\
\hline 4-day Control with recovery vs. & 3.17 & $.002 * *$ & 2.17 & $.021 *$ \\
\hline 4-day RSD & & & & \\
\hline
\end{tabular}

$\mathrm{p}$ values for one-tail test

${ }^{*} p<.05 .{ }^{* *} p<.01$ 


\section{Esd Effects}

13

Figure Caption

Figure 1. Means of the Number of Stimulus Trains Required to Produce an Epileptiform Response. 


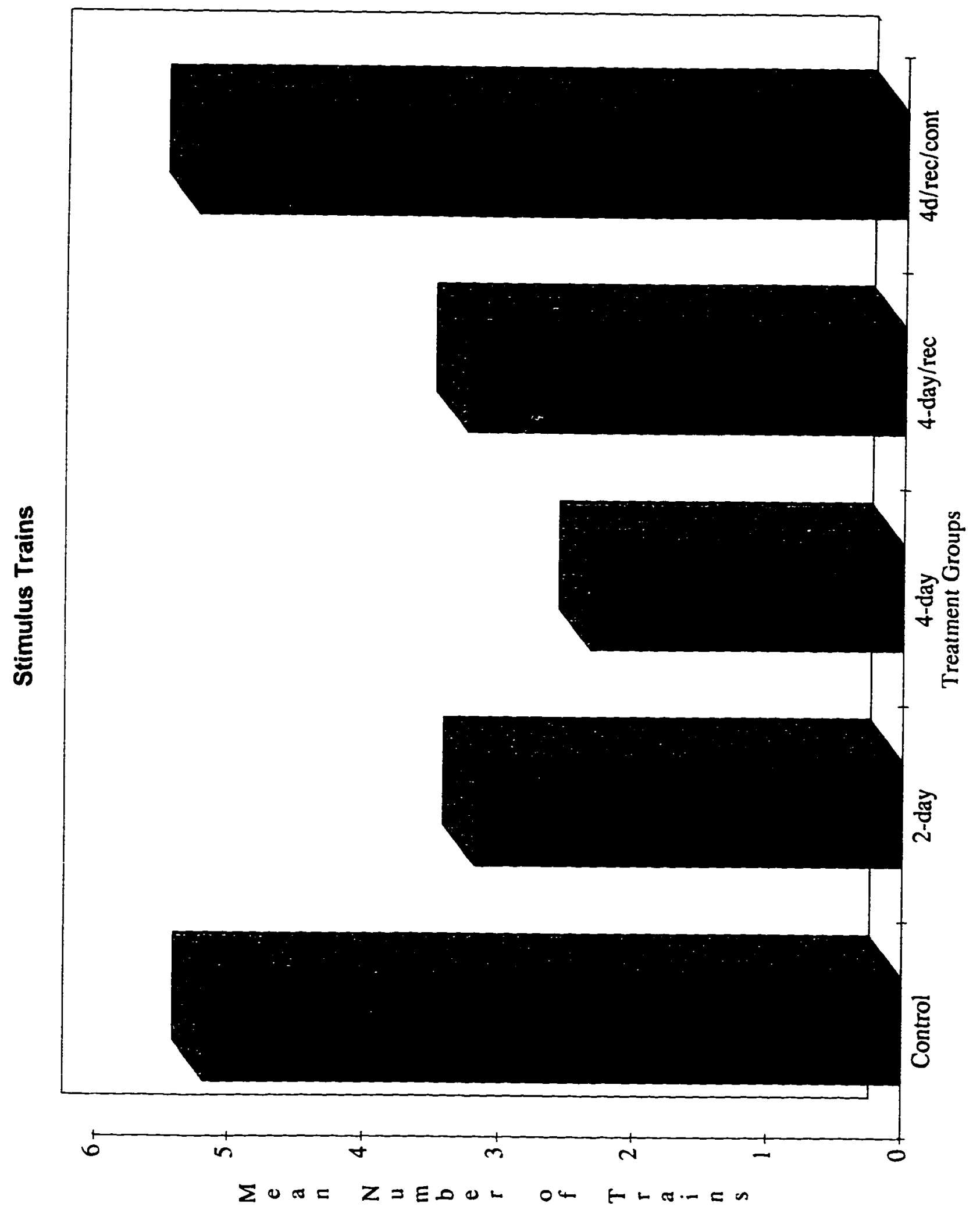


Esd Effects

15

Figure Caption

Figure 2. Means for the Number of Population Spikes Present after 10 Stimulus Trains. 


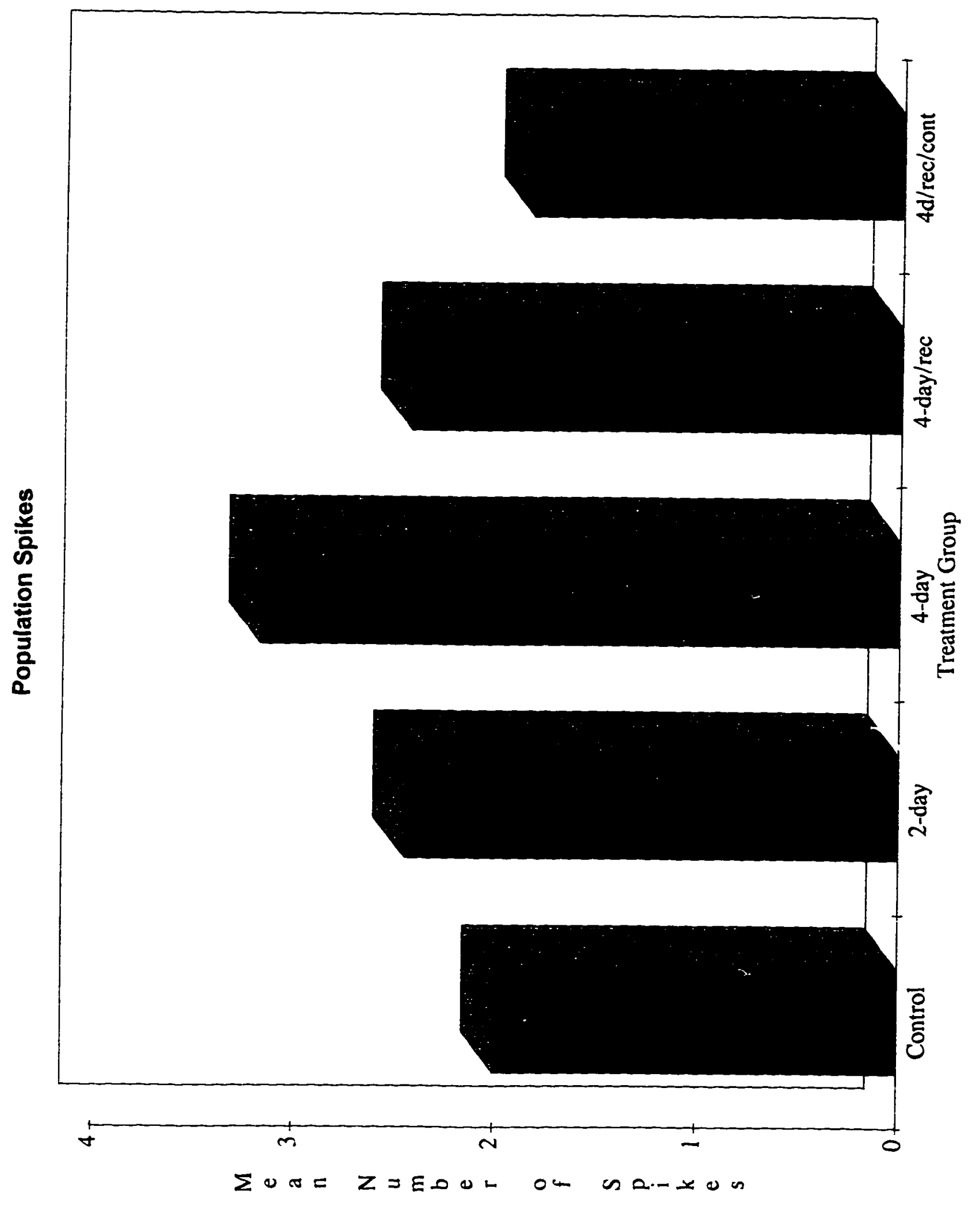




\section{Esd Effects}

17

\section{Discussion}

The purpose of this study was to examine the relationship between RSD and seizure-like activity. The data suggest that rats which are deprived of REM sleep are more susceptible to electrical epileptogenic stimuli than rats that are not deprived of REM sleep. These results support my hypothesis that REM sleep may be an inhibitor of epileptiform activity. The results are also consistent with those of prior studies which assert that REM sleep has inhibitory effects on seizures (Billiard et al., 1987: Cohen \& Dement, 1966; Cohen et al., 1970; Montplaisir et al., 1982,1985,1987a, 1987b; Sammaritano et al., 1991; Shouse et al., 1990). The research of both Shouse et al. (1990) and Cohen \& Dement (1966), are particularly relevant to this study because they used a temporal lobe epilepsy model and electrical stimulation to induce seizures. Recovery Effect and Dose Response

The mean number of population spikes for the recovery groups was less than that for the 4-day RSD group. Similarly, the mean number of stimuli required to produce an epileptiform response was greater in the recovery group than the RSD group. Although not statistically significant, the difference between the means of the two control groups and the recovery group suggest that RSD rats may actually recover from the effects of RSD. I used a 4-day recovery period; however, one might speculate that with a longer recovery period the responses of the rats may have returned to control values. 


\section{Esd Effects}

18

The results also suggest that the susceptibility of the slices to electrical epileptiform stimuli was dependent upon the amount of time that the rats were REM sleep deprived, or in other words that there was a dose of RSD that resulted in statistically significant effects on the epileptiform responses of the hippocampal slices.

\section{Lasting Effects}

A provocative result of this study was that the effects of REM deprivation were of a lasting nature in that they were preserved in vitro. This suggests that REM deprivation causes changes in the hippocampus that are not rapidly reversed when the tissue is removed from its native environment and separated from its normal neuronal connections. These changes might include alterations in the number and sensitivity of neurotransmitter receptors, changes in the neurotransmitter synthesizing enzymes, alterations in reuptake mechanisms, anatomical changes or changes in neuronal membrane properties. Whatever may be occurring, the results of this study suggest the hippocampal slice is a useful model to study at least some aspects of REM deprivation.

\section{Limitations of the Study}

One of the limitations of this study was that it only examined one model of epilepsy. Epileptiform activity in the hippocampus most closely models partial temporal lobe epilepsy. It is important to realize that there are many different types of epilepsy (absence, grand mal, etc.) which may respond to RSD in different ways. This is supported by the diversity of the results reported among authors that used 


\section{Esd Effects}

different models of epilepsy. Another limitation of this study was that the evaluation of the effects of RSD on epileptiform activity was done in vitro as opposed to in vivo. There may be some effects of RSD that can only be observed in vivo.

\section{Suggestions for Future Research}

In vivo experiments which examine the rats during their naturally occurring sleep states, after RSD, and during recovery periods may provide more insight about the effects of RSD on stimulus-induced epileptiform activity. Future studies also might examine the effects of longer recovery periods and longer periods of RSD. A question that arises from this study is "If REM sleep is a inhibitor of epileptiform activity, then what occurs during REM sleep that may suppress seizure-like activity." Perhaps this is a question that may warrant future research. Further insight may also be gained by examining the cellular mechanisms that underlie REM sleep. Finally, all of these questions should be examined using multiple models of epilepsies.

\section{Conclusion}

The data suggest that REM sleep is an inhibitor of epileptiform activity. In other words, preventing the processes of REM sleep may make brain tissue more likely to exhibit seizure activity. The results of this study provide a better understanding of the relationship between REM sleep and seizures and contribute to the knowledge base available for the development of treatments for epileptic seizures.

One interesting result of this study is that the effects of REM deprivation were of a 


\section{Esd Effects}

20

lasting nature in that they were maintained in vitro. This suggests that REM deprivation causes changes in the hippocampus that are not rapidly reversed when the tissue is removed from its native environment and separated from the normal neuronal connections. These changes might include alterations in the numbers of neurotransmitter receptors or synthesizing enzymes, alterations in uptake mechanisms, anatomical changes or changes in neuronal membrane properties. 


\section{Esd Effects}

\section{References}

Billiard, M., Besset, A., Zachsriev, Z., Touchon, J., Baldy, Moulinier, M., Cadihac, J., (1987). Relation of seizures and seizure discharges to sleep stages. In Wolf, P., Dam, M., Janz, D., Driefuss, M., (Eds.), Advances in Epiletology (pp. 665-670). New York: Raven Press.

Cadihac,J., (1982). Complex partial seizures and REM sleep. In Sterman, M.B., Shouse, M.N., Passouant, P., (Eds.), Sleep and Epilepsy (pp. 315-324). New York:Academic Press.

Cohen, H.B., and Dement, W.C., (1965). Sieep changes in threshold to electroconvulsive shock in rats after deprivation of paradoxical phase. Science, 150 , 1318.

Cohen, H.B., and Dement, W.C., (1966). Sleep suppression of rapid eye movement phase in the cat after electroconvulsive shock. Science, 154, 396.

Cohen, H., Thomas, J., and Dement, W. C., (1970). Sleep stages, REM deprivation, and electroconvulsive threshold in the cat. Brain Research, 19, 317.

Haas, H.L., Schaerer,B., and Vosmansky, M. (1979). A simple perfusion chamber for the study of nervous tissue slices in vitro. Journal of Neuroscience Methods, 1. 323.

Hicks, R.A., Gomez, S., Gonzales, M., McTighe, S., and Ortiz, D., (1988). REM sleep deprivation and drinking in rats: A test of Vogel's theory. Bulletin of the Psychonomic Society, 26 (2), 132.

Hopkins, A. and Garman, A. (1987) The causes and precipitation of seizures. In Hopkins, A. (Ed.), Epilepsy (pp. 124-126). New York: Demos Publications.

Horita, H., Uchida, E., Maekawa, K., (1991). Circadian rhythm of regular spike wave discharges in childhood absence epilepsy. Brain Development 13, 200.

Montplasir, J., Laverdiere, M., Saint-Hilaire, J.M., (1982). Sleep and focal epilepsy: contribution of depth recording. In Sterman, M.B., Shouse, M.N., (Eds.), Sleep and Epilepsy (pp. 301-314). New York: Academic Press. 


\section{Esd Effects}

Montplasir, J., Laverdiere, M.., Saint-Hilaire, J.M., (1985). Sleep and epilepsy. In Gotman, J., Ives, J., Gloor, P., (Eds.), Long-Term Monitoring in Epilepsy. ERG supplement no.37, (pp. 215-239). Amsterdam: Elsevier Science Publisher B.V. (Biomedical Division).

Montplasir, J., Laverdiere, M., Saint-Hilaire, J.M., Rouleau, L., (1987a). Nocturnal sleep recordings in partial epilepsy: a study with depth electrodes. Journal of Clinical Neurophysiology .4, 383.

Montplasir, J., Laverdiere, M., Saint-Hilaire, J.M., and Rouleau, L., (1987b). Sleep and focal epilepsy: a study of patients implanted with depth electrodes. In Wolf, P., Dam, M., Janz, D., Drefuss, M., (Eds.), Advances in Epiletology (pp.705-707). New York: Raven Press.

Palestini, M., Pisano, M., Rosadini, G., and Rossi, G.F., (1965). Excitability cycle of the visual cortex during sleep an wakefulness. EEG Clinical Neurophysiology, 19, 276.

Passount, P., (1984). Historical aspects of sleep and epilepsy. In Degen, R., \& Niedermeyer (Eds.), Epilepsy, Sleep and Sleep Deprivation, (pp.67-73). New York: Elsevier.

Peeters, B.W.M.M., Van Luijtelaar, E.L.J.M., and Coenen, A.M.L., (1988). Absence epilepsy in rat is reduced by deprivation of REM sleep. Physiology of Behavior, 46, 115 .

Rossi, G.F., Colicchio, G., Pola, P., and Roselli, R., (1984). Sleep and epileptic activity. In Degen, R., \& Niedermeyer (Eds.), Epilepsy. Sleep and Sleep Deprivation, (pp. 35-46). New York: Elsevier.

Rossi, G.F., Colicchio, G., Pola, P., Roselli, R., and Rosadini, G., (1965).An Experimental study of the cortical reactivity during sleep and wakefulness.

In: Du Centre National de la Recherche Scientifique (Eds):, Colloques Internationaux Centre National de la Recherche Scientifique: Aspects Anatomo-Fonctionels de la Physiologie du Sommeil, (pp.509-526). Lyon.

Sammaritano, M., Gigli, G.L., and Gotman, J. (1991). Interictal spiking during wakefulness and sleep and the localization of foci in temporal lobe epilepsy. Neurology, 41, 290. 


\section{Esd Effects}

Schwartzkroin, P. A., and Prince, D. A., (1978). Cellular and field potential properties of epileptogenic hippocampal slices. Brain Research, 147, 117.

Shouse, M.N., Langer, J.V., and Dittes P.R., (1990). Spontaneous sleep epilepsy in amygdala kindled kittens: a preliminary report. Brain Research, 535, 163.

Yamamoto, C., (1972). Intracellular study of seizure-like after discharges elicited in thin hippocampal sections in vitro. Experimental Neurology, 35, 154.

Yamamoto, C., and Kawai, N., (1968). Generation of the seizure discharges in thin section of the guinea pig brain in chloride-free medium in vitro. Japanese Journal Physiology 18,620. 